\title{
INFLUENCE OF POPULATION AGEING ON MACROECONOMIC PRODUCTIVITY
}

\author{
MARTINA ŠIMKOVÁa, ${ }^{\mathrm{a},}$, JAROSLAV SIXTA ${ }^{\mathrm{b}}$ \\ martina.simkova@vse.cz, sixta@vse.cz \\ a University of Economics in Prague, Faculty of Informatics and Statistics, Department of Demography, \\ W. Churchill Sq. 4, Prague, Czech Republic \\ b University of Economics in Prague, Faculty of Informatics and Statistics, Department of Economic Statistics, \\ W. Churchill Sq. 4, Prague, Czech Republic
}

\begin{abstract}
Labour force of all European countries is ageing and this natural demographic process has its own consequences on economic output and productivity. This issue has been widely discussed in Western countries for several years, but a deep economic and social discussion is still absent in the Czech Republic. The paper studies the impact of ageing on the level of income of workers stratified by age, level of education or industry. The most challenging issue is the decomposition of growth into a general increase in productivity, the effect specific to a particular industry, and the effect of demographic ageing. All these effects have affected the development of Czech labour force in the last decade. The data for the analysis are sourced from the Labour Force Survey and Average Earnings Information System maintained by the Czech Statistical Office and are combined with national accounts figures. Specifics of the Labour Force Survey are taken into account, and data are transformed to be consistent with the methodology of contemporary macroeconomic indicators.
\end{abstract}

\section{Key words}

ageing, productivity, labour force

\section{JEL classification}

E24, J11, J21

\section{Introduction}

The issue of the productivity is a relevant topic for economic studies despite it was many discussed and investigated. We also bring new motives for studying productivity as a key parameter of society development. The ongoing changes in productivity due to human development are difficult to predict but the there are some areas of economic life where it is possible and necessary. We focus on the problem of demographic ageing and its impact on the Czech economy. Of course, the impacts are quite broader including society, ecology etc. but we focus just on the economy. The impact on the economy can be measured from two sides, the first is from the supply side covering production based on labour and capital and the second is from the demand side respecting changing habit of households and government policy that is reflected in their consumption expenditures. Within this paper we focus briefly on the supply side of the economy that contains mainly the changes in the composition of labour including its quality.

Population ageing affects the labour force in several ways. In addition, a performance of organizations in the forthcoming years is affected since we may face a brain drain and a talent gap. Both the private and the public sector will face a shortage of qualified personnel. The knowledge is a key factor that affects the output and performance and ageing labour force may lead to the decrease of the ability of organizations to be knowledge productive (Stam, 2009). We have serious concerns about a slowdown in economic growth due to the lack of young 
people on the labour market, the ageing labour force or possible unemployment of older workers (Miskolczi et al., 2011). The fundamental issue is how the change of the population will be influenced in terms of available resources (real output). Therefore, we focus on the issue of productivity that can be positively or negatively influenced by population ageing and for this purpose we use selected macroeconomic indicators and demographic projections. Since the productivity is hard to measure, we use wages and value added broken down by age, educational or industrial level. The key logic behind is the impact of ageing on the level of income of workers and consequences for the population. Our paper brings new view on demographic ageing in Czech context since such analyses are missing in the Czech Republic. In foreign countries, experts started this discussion few years ago. We wanted to express that ageing should be also considered from economic point of view where the productivity issue may not be avoided.

\section{Literature overview}

The impacts of demographic processes on the economy is not straightforward that results from number of studies published in developed countries. Many worldwide studies put the question about ability of ageing and shrinking labour force to maintain economic growth, public finances, social security systems and prosperity (Lassila and Valkonen, 2008).

Closely related with hesitating of employers about employing older people is the question, if an older worker is more or less productive than younger one. Some studies confirm the significance of the factor of laborforce age (e.g Prskawetz et al., 2005; Grönqvist, 2009; or Mahlberg et al., 2013b). There are several reasons to worry about lower productivity of older workers compared to younger workers. Different ability to adopt of new technologies can be significant reason. Younger workers are beneficiaries of new technologies that are usually more productive than older ones. The similar situation can occur for computer skills and internet use (Newburger, 2001). Tang and MacLeod (2006) present a work effort as significant difference between younger and older workers. It means that younger workers spent more time working at the workplace as well as higher level of pace than older workers. Older labour force has lower potential for economic innovation, professional and occupational mobility.

There are several analyses about the relationship of ageing and productivity, at individual level (Skirbekk, 2008), organization level (Aubert and Crépon, 2003), national level (Prskawetz et al., 2007) or industry level (Mahlberg et al., 2013a). There are also some studies about ageing and productivity at occupational level (Oster and Hamermesh, 1998). However, there are not many studies on the effects of the age structure on aggregate productivity in economics. Junka (2003) look in detail at the factors that have contributed to aggregate productivity in 1976 - 2005 and 1975 - 2000 respectively. Grönqvist (2009) use an econometric approach in line with Tang and MacLeod (2006) to estimate the effects of the changing age structure on productivity in Finland. According to Venn (2008), productivity may also differ across different occupations and aggregated impact would be sensitive to the industrial structure of the economy. It is provided a taxonomy of economic sectors distinguished by their exposure to workforce aging risks (Aiyar et al., 2016). We can find professions in which the productivity increases with age, with neutral impact and with negative impact on the productivity. Of course, the impact is vitally connected with the nature of the work. It is clear that physically demanding work in the factory will be treated differently than the work of the university professor or lawyer. The study of International Monetary Fund (IMF) works with the impact on the total factor productivity about 0.1 percentage point. In other words, it means that growth of the total factor productivity (TFP) will be lowered by population ageing annually by 0.1 percentage points. 


\section{Labour productivity measurement}

Output and gross value added is measured within the system of national accounts and therefore we have to start with macroeconomic data. The productivity is usually defined as a production in relation to inputs to the production process. In terms of labour productivity it means output or gross value added per a worker. In order to avoid double counting we use only gross value added and as a labour input we use number of workers expressed in full time equivalent (FTE) using the formula

$$
g=Y / L,
$$

where $Y$ is gross value added and $L$ is number of workers (full time equivalent).

Macroeconomic labour productivity for the period between 1995 and 2017 in industries (according to the NACE classification, see the Appendix) is shown in Table 1. The productivity is expressed in thousands Czech Koruna $(\mathrm{CZK})$ per worker per year. Historically, the lowest labour productivity was in agriculture (A) and trade (G) in the Czech Republic. However, the relations have changed since 1995 . Labour productivity increased by $130.7 \%$ in agriculture and by $256.5 \%$ in IT (J) between 1990 and 1995, on the contrary, the labour productivity in trade dropped nearly by $50 \%$. The average annual growth rate of labour productivity was about $2.4 \%$ during the whole period from 1995 to 2017. That proves solid economic development creating resources. The highest increase was in trade $(5.9 \%)$, banking $(\mathrm{K}, 3.6 \%)$, manufacturing (B-E, 3.5\%) and agriculture (2.4\%).

Table 1: Macroeconomic labour productivity by industries (in CZK thousands)

\begin{tabular}{|c|c|c|c|c|c|c|c|c|c|c|c|c|c|}
\hline & \multicolumn{2}{|c|}{1995} & \multicolumn{2}{|c|}{2000} & \multicolumn{2}{|c|}{2005} & \multicolumn{2}{|c|}{2010} & \multicolumn{2}{|c|}{2015} & \multicolumn{2}{|c|}{2017} & \multirow{2}{*}{$\begin{array}{l}\text { Avg. } \\
\text { growth rate }\end{array}$} \\
\hline & Value & $\mathrm{I}_{\mathrm{t} / \mathrm{t}-5}$ & Value & $\mathrm{I}_{\mathrm{t} / \mathrm{t}-5}$ & Value & $\mathrm{I}_{\mathrm{t} / \mathrm{t}-5}$ & Value & $\mathrm{I}_{\mathrm{t} / \mathrm{t}-5}$ & Value & $\mathrm{I}_{\mathrm{t} / \mathrm{t}-5}$ & Value & $\mathrm{I}_{\mathrm{t} / \mathrm{t}-5}$ & \\
\hline Total & 469 & 1.019 & 533 & 1.137 & 638 & 1.197 & 714 & 1.118 & 762 & 1.068 & 794 & 1.042 & 1.024 \\
\hline A & 261 & 2.307 & 290 & 1.111 & 442 & 1.522 & 379 & 0.858 & 435 & 1.147 & 442 & 1.017 & 1.024 \\
\hline B-E & 397 & 0.763 & 463 & 1.168 & 593 & 1.281 & 789 & 1.330 & 791 & 1.002 & 852 & 1.077 & 1.035 \\
\hline $\mathrm{F}$ & 568 & 0.621 & 477 & 0.839 & 530 & 1.111 & 521 & 0.983 & 585 & 1.122 & 563 & 0.964 & 1.000 \\
\hline G & 198 & 0.527 & 295 & 1.490 & 473 & 1.601 & 520 & 1.100 & 664 & 1.277 & 695 & 1.047 & 1.059 \\
\hline $\mathrm{H}$ & 683 & 0.704 & 705 & 1.033 & 734 & 1.041 & 709 & 0.966 & 619 & 0.873 & 652 & 1.053 & 0.998 \\
\hline I & 818 & 1.084 & 699 & 0.854 & 427 & 0.611 & 346 & 0.809 & 373 & 1.079 & 372 & 0.997 & 0.965 \\
\hline $\mathrm{J}$ & 943 & 3.565 & 1063 & 1.127 & 1388 & 1.306 & 1428 & 1.029 & 1676 & 1.174 & 1705 & 1.018 & 1.027 \\
\hline K & 1142 & 1.068 & 1397 & 1.223 & 1345 & 0.963 & 1960 & 1.457 & 2130 & 1.086 & 2490 & 1.169 & 1.036 \\
\hline L-N & 1178 & 1.130 & 1134 & 0.962 & 1138 & 1.004 & 1076 & 0.946 & 1192 & 1.107 & 1215 & 1.020 & 1.001 \\
\hline $\mathrm{O}$ & 638 & 1.303 & 634 & 0.995 & 731 & 1.151 & 785 & 1.074 & 828 & 1.055 & 812 & 0.980 & 1.011 \\
\hline $\mathrm{P}$ & 547 & 1.397 & 530 & 0.969 & 522 & 0.986 & 547 & 1.047 & 560 & 1.023 & 551 & 0.984 & 1.000 \\
\hline Q & 611 & 1.129 & 543 & 0.889 & 574 & 1.057 & 500 & 0.872 & 454 & 0.907 & 451 & 0.995 & 0.986 \\
\hline $\mathrm{R}$ & 946 & 1.563 & 736 & 0.778 & 700 & 0.951 & 579 & 0.827 & 634 & 1.094 & 653 & 1.030 & 0.983 \\
\hline S-U & 802 & 1.167 & 579 & 0.722 & 483 & 0.836 & 401 & 0.829 & 385 & 0.961 & 368 & 0.957 & 0.965 \\
\hline
\end{tabular}

Note: $\mathrm{I}_{\mathrm{t} / \mathrm{t}-5}$ represents index of change in labour productivity between current period $(\mathrm{t})$ and five years ago $(\mathrm{t}-5)$. Source: the authors.

In reality, labour productivity itself does not provide adequate information when we do not know the share of labour compensation in value added. It means that we need to know what the overall employees' costs by industry is. The share of compensation of employees on gross value added at current prices is shown on the Table 2 . The overall figures show that $43 \%$ of gross value added was "paid" to employees in 1995 and 46\% in 2017. In relation with the information in Table 1, employees share decreased significantly in agriculture (A), construction $(\mathrm{F})$ and banking $(\mathrm{K})$ industries. It is obvious, since technological progress and availability of modern efficient technologies substitutes labour in these industries. This can be hardly valid for personnel demanding industries such as education $(\mathrm{P})$ and health and social care $(\mathrm{Q})$. 
Table 2: Share of compensation of employees on gross value added by industries

\begin{tabular}{llllllll}
\hline & 1995 & 2000 & 2005 & 2010 & 2015 & 2017 & $2017 / 1995$ \\
\hline Total & 0.43 & 0.42 & 0.44 & 0.44 & 0.44 & 0.46 & 1.072 \\
A & 0.46 & 0.46 & 0.47 & 0.55 & 0.38 & 0.39 & 0.866 \\
B-E & 0.44 & 0.45 & 0.45 & 0.44 & 0.43 & 0.46 & 1.053 \\
F & 0.57 & 0.48 & 0.42 & 0.42 & 0.39 & 0.39 & 0.695 \\
G & 0.44 & 0.41 & 0.44 & 0.51 & 0.48 & 0.49 & 1.097 \\
H & 0.37 & 0.42 & 0.47 & 0.48 & 0.48 & 0.50 & 1.353 \\
I & 0.25 & 0.26 & 0.41 & 0.42 & 0.46 & 0.47 & 1.902 \\
J & 0.36 & 0.33 & 0.34 & 0.39 & 0.41 & 0.43 & 1.188 \\
K & 0.40 & 0.49 & 0.45 & 0.31 & 0.34 & 0.35 & 0.878 \\
L-N & 0.22 & 0.21 & 0.23 & 0.25 & 0.25 & 0.26 & 1.165 \\
O & 0.59 & 0.61 & 0.62 & 0.62 & 0.62 & 0.66 & 1.103 \\
P & 0.66 & 0.65 & 0.71 & 0.71 & 0.70 & 0.72 & 1.092 \\
Q & 0.63 & 0.62 & 0.64 & 0.71 & 0.73 & 0.76 & 1.211 \\
R & 0.41 & 0.35 & 0.41 & 0.45 & 0.47 & 0.50 & 1.219 \\
S-U & 0.24 & 0.27 & 0.32 & 0.41 & 0.42 & 0.45 & 1.886 \\
\hline Source & & & & & & &
\end{tabular}

Source: the authors.

The change of the total number workers is observed due to the increase of the statutory retirement age. Up to now, the average age in the population is rising but due to the low fertility the share of young people is constantly decreasing. This, of course, implies an increase in the average age of employees in the Czech economy. The development of the number of workers is seen in Figure 1. The overall number of workers rise between 1995 and 2017 by $2.9 \%$ to 5.25 million workers. The period of 23 year is long enough to see structural economic changes.

Figure 1: Development of the number of workers express in FTE by industries

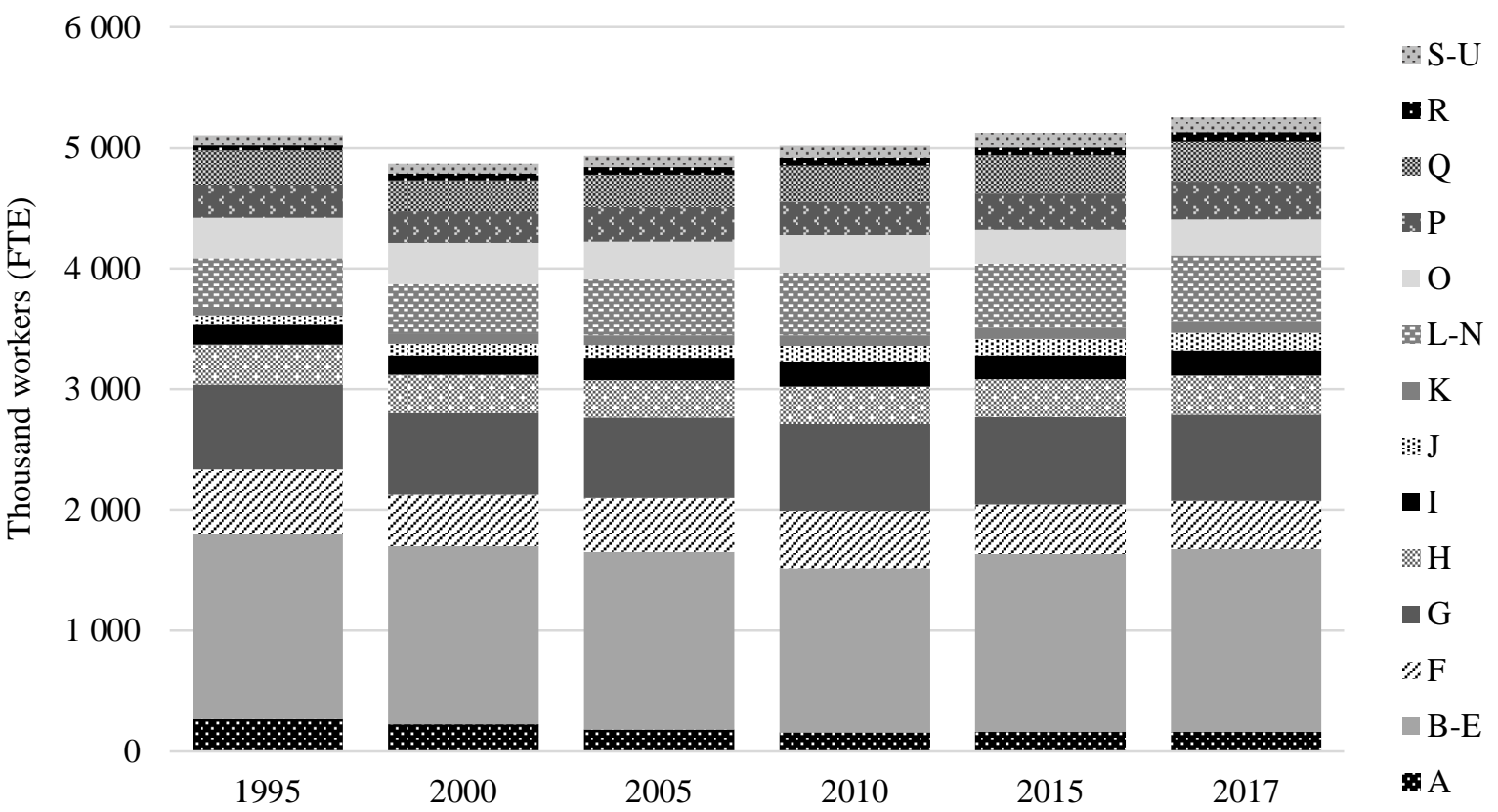

Source: the authors based on data from the Czech Statistical Office.

\section{Ageing and productivity}

The unique data source that can provide employment by age and industry is Labour Force Survey (LFS). This traditional data source aims household and measures both employees and self-employed. It allows us to present average age of the workers by industries, see Figure 2. It is not a surprise that the "youngest" industries comprise IT $(\mathrm{J})$, transport services $(\mathrm{H})$ and banking $(\mathrm{K})$. On the contrary, into the group of the "oldest" industries belong mainly agriculture 
$(\mathrm{A})$, construction $(\mathrm{F})$, education $(\mathrm{P})$ and health $(\mathrm{Q})$. The difference of 8.2 years between the youngest and the oldest industries indicate long run imbalance. The potential effect of old workers in health may have serious consequences not only on the productivity itself but also on the condition of the population.

Figure 2: Average age of workers by industries, 2017

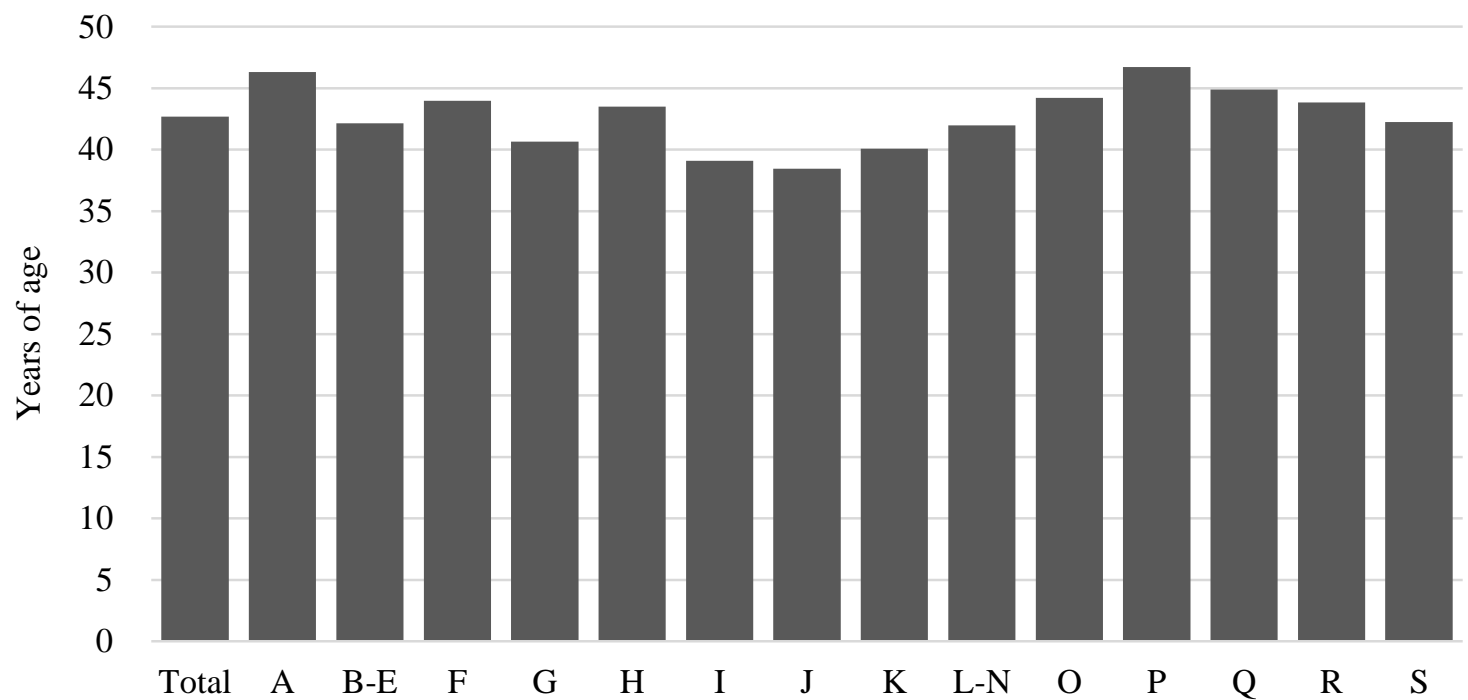

Source: the authors based on data from the Czech Statistical Office.

Despite methodological differences from national accounts, this provides an interesting comparison about the impact of ageing on particular industries, see Figure 3. The drop in the age group of 15-24 years is obvious but also relates to the higher demand for university education by youth (of course, it stands for the youth who do not work). On the contrary, the increase of the share of bars on top of the figure responds to the increase of older workers. Between 1997 and 2017 the total share of workers above 55 years increased by 9 percentage points and reached $18.3 \%$ in total productive population. Among the most affected industries by population ageing belong agriculture $(\mathrm{A})$, construction $(\mathrm{F})$ and health care $(\mathrm{Q})$. Construction and health care are very labour intensive industries, the number of workers varies between $9.6 \%$ (in 1997) and 7.6\% (in 2017) and 5.0\% (in 1997) and 6.4\% (in 2017) respectively.

Figure 3: Structure of employment in the Czech Republic by age groups and industries (in \%)

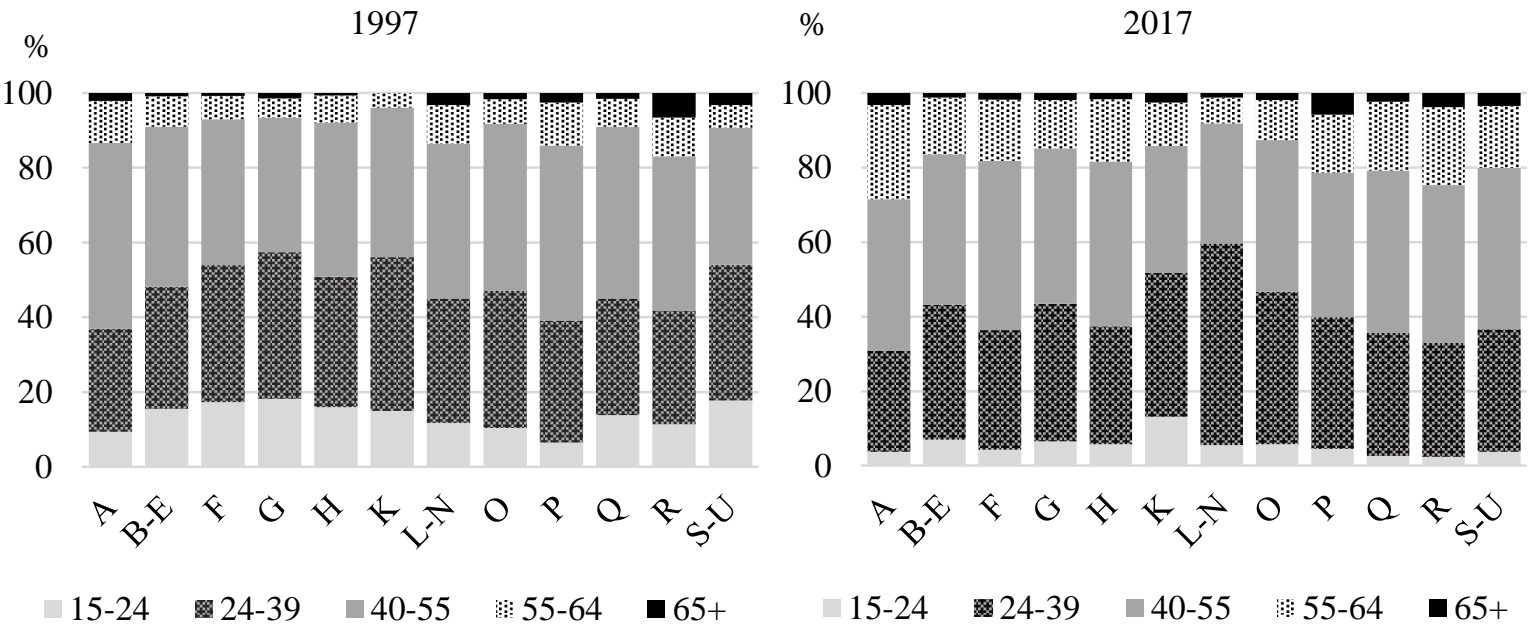

Source: the authors. 
The crucial proxy for productivity measurement is a wage. This distribution of the monthly wages represents very important information (see Figure 4).

Figure 4: Average monthly wages by age and education level for 2017 (in CZK)

60000

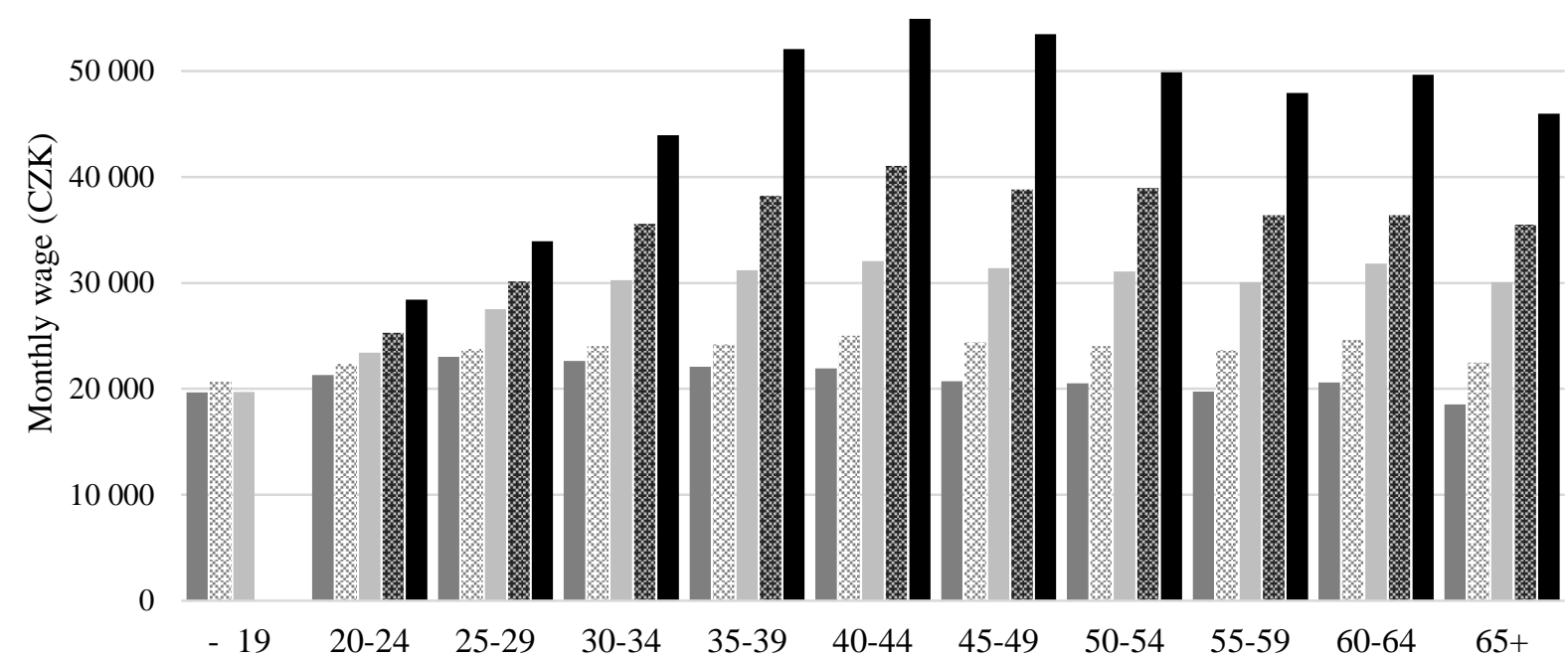

- Primary and incomplete education

Secondary education without A-level examination

Secondary education with A-level examination

Post-secondary non-tertiary and bachelor's education

- Higher education

Source: the authors.

Figure 4 shows that people earn the highest wages between 35 and 59 years of their life. This is valid mainly for people that are more educated; secondary school and university degree. It is obvious that for the works requiring low qualification, younger workers can be more productive and therefore have higher wages. Of course, there are also very high wages in the age group 60 to 64 for higher educations. However, this group is relatively smaller and specific containing university professors or doctors and hardly comparable across educational level. If we assume that wages are distributed according the marginal productivity and use this indicator as a proxy for productivity measurement for ageing, we obtain relative productivity measures, see Table 3. Relative Productivity Measures (RPM) describe the productivity of the age groups in relation to the country average. Productivity is estimated as a labour based productivity, i.e. according to marginal productivity per worker (wages per worker by different stratification groups). It is derived from average wages by age-groups and level of education. It shows how much is a particular age-group more or less productive in relation to the average with the same education level.

For the computational purposes, we use the average for the years 2017 and 2007 (latest available). We selected ten-year period for better expressing the changes in the society. For example, people with the university degree in the age group 65+ are less productive than people in the age group 40-44 by 0.16 percentage points (1.12-0.96). Similarly, people with the lowest education in the age group 30-34 are the most productive. 
Table 3: Relative productivity measures by age and education level (annual average $=100$ )

\begin{tabular}{|c|c|c|c|c|c|c|c|c|c|c|c|c|c|c|c|}
\hline & \multicolumn{3}{|c|}{$\begin{array}{l}\text { Primary and } \\
\text { incomplete } \\
\text { education }\end{array}$} & \multicolumn{3}{|c|}{$\begin{array}{c}\text { Secondary } \\
\text { education without } \\
\text { A-level } \\
\text { examination }\end{array}$} & \multicolumn{3}{|c|}{$\begin{array}{c}\text { Secondary } \\
\text { education with } \\
\text { A-level } \\
\text { examination }\end{array}$} & \multicolumn{3}{|c|}{$\begin{array}{l}\text { Post-secondary } \\
\text { non-tertiary and } \\
\text { bachelor's } \\
\text { education }\end{array}$} & \multicolumn{3}{|c|}{ Higher education } \\
\hline & 2007 & 2017 & $\mathrm{AVG}$ & 2007 & 2017 & $\overline{A V G}$ & 2007 & 2017 & $\mathrm{AVG}$ & 2007 & 2017 & $\mathrm{AVG}$ & 2007 & 2017 & $\mathrm{AVG}$ \\
\hline-19 & 0.80 & 0.93 & 0.86 & 0.75 & 0.86 & 0.81 & 0.58 & 0.65 & 0.62 & 0.00 & 0.00 & 0.00 & 0.00 & 0.00 & 0.00 \\
\hline $20-24$ & 0.94 & 1.00 & 0.97 & 0.88 & 0.93 & 0.91 & 0.75 & 0.77 & 0.76 & 0.68 & & 0.69 & 0.53 & 0.59 & 0.56 \\
\hline $25-29$ & 1.04 & 1.08 & 1.06 & 1.00 & 0.98 & 0.99 & 0.95 & 0.91 & 0.93 & 0.88 & 0.85 & 0.87 & 0.71 & 0.70 & 0.70 \\
\hline $30-34$ & 1.08 & 1.06 & 1.07 & 1.04 & 1.0 & 1.02 & 1.08 & 1.00 & 1.04 & 1.16 & 1.00 & 1.08 & 1.02 & 0.91 & 0.96 \\
\hline $35-39$ & 1.07 & 1.04 & 1.05 & 1.02 & 1.00 & 1.01 & 1.05 & 1.03 & 1.04 & 1.19 & 1.08 & 1.13 & 1.16 & 1.08 & 1.12 \\
\hline $40-44$ & 1.03 & 1.0 & 1.03 & 1.01 & 1.04 & 1.02 & 1.01 & 1.06 & 1.04 & 1.12 & 1.16 & 1.14 & 1.11 & 1.14 & 1.12 \\
\hline $45-49$ & 0.99 & 0.97 & 0.98 & 0.99 & 1.01 & 1.00 & 1.01 & 1.04 & 1.02 & 1.09 & 1.09 & 1.09 & 1.03 & 1.11 & 1.07 \\
\hline $50-54$ & 0.97 & 0.96 & 0.97 & 0.99 & 1.00 & 0.99 & 1.02 & 1.03 & 1.02 & 1.07 & 1.10 & 1.09 & 1.02 & 1.03 & 1.03 \\
\hline $55-59$ & 1.00 & 0.93 & 0.96 & 1.01 & 0.98 & 0.99 & 1.04 & 0.99 & 1.02 & 1.07 & 1.02 & 1.05 & 1.02 & 0.99 & 1.00 \\
\hline $60-64$ & 0.97 & 0.97 & 0.97 & 1.04 & 1.02 & 1.03 & 1.12 & 1.05 & 1.09 & 1.06 & 1.02 & 1.04 & 1.02 & 1.03 & 1.02 \\
\hline $65+$ & 0.75 & 0.87 & 0.81 & 0.78 & 0.93 & 0.86 & 0.90 & 0.99 & 0.95 & 0.88 & 1.00 & 0.94 & 0.97 & 0.95 & 0.96 \\
\hline
\end{tabular}

Source: the authors.

\section{Estimated labour productivity index}

There are several ways how the present changing productivity and we use index approach. For the description of current state of art and for future research, we construct Estimated Labour Productivity Index (ELPI). This index is composed from data describe above, labour productivity, demographic projection and macroeconomic statistics. Such index combines demographic situation and long trends in development. We define ELPI as

$$
I_{E L P}=I_{T E C H} I_{D E M} I_{A V G},
$$

where $I_{E L P}$ is estimated labour productivity index, $I_{T E C H}$ is technological development, $I_{D E M}$ is demographic development and $I_{A V G}$ is average development of the industry.

For the purposes of our paper, we suppose that technological development is a unit index since we can focus on the expression of ageing only. The technological progress is an important issue that is studied by the Ministry of Finance or the Czech National Bank for their predictions of economic development. We focus on the demographic part of ELPI that is comes from the combination of demographic projection of the Czech Republic published by the Czech Statistical Office ${ }^{1}$ and RPM. The long-term development of the industry should represent the demand for products of a particular industry and not in the scope of interest for our paper. The demographic part of ELPI is crucially affected by the demographic wave and for the comparison of the pure demographic effect of productivity we suppose the same educational structure of population and the same rate of the economic activity as in 2018. The development of IDEM is shown on the Figure 5. We present it as a base index with the base in the year 2018. Different relations of RPM in the population causes the expected development of demographic wave is not completely respected and all effect mentioned above are clearly visible. The highest negative impact is observed for primary and incomplete and secondary education without Alevel examination. On the contrary, productivity of people with higher education will be affected relatively slightly. We estimate the overall average annual decrease $0.021 \%$ that is significantly lower than $0.1 \%$ estimated by the IMF. However, our figures count with expected population development with relatively positive development in the first 40 years and with the decline later while the IMF counts net negative effects.

\footnotetext{
${ }^{1}$ Available at: https://www.czso.cz/csu/czso/projekce-obyvatelstva-ceske-republiky-2018-2100 (accessed 2019-03-01).
} 
In reality, the situation is more complex. We expect that population ageing not only in the Czech Republic will be partly compensated by the increase of the rate of economic activity, better health condition of the workers and increase of the statutory retirement age.

Figure 5: Demographic contribution to the productivity growth by education level

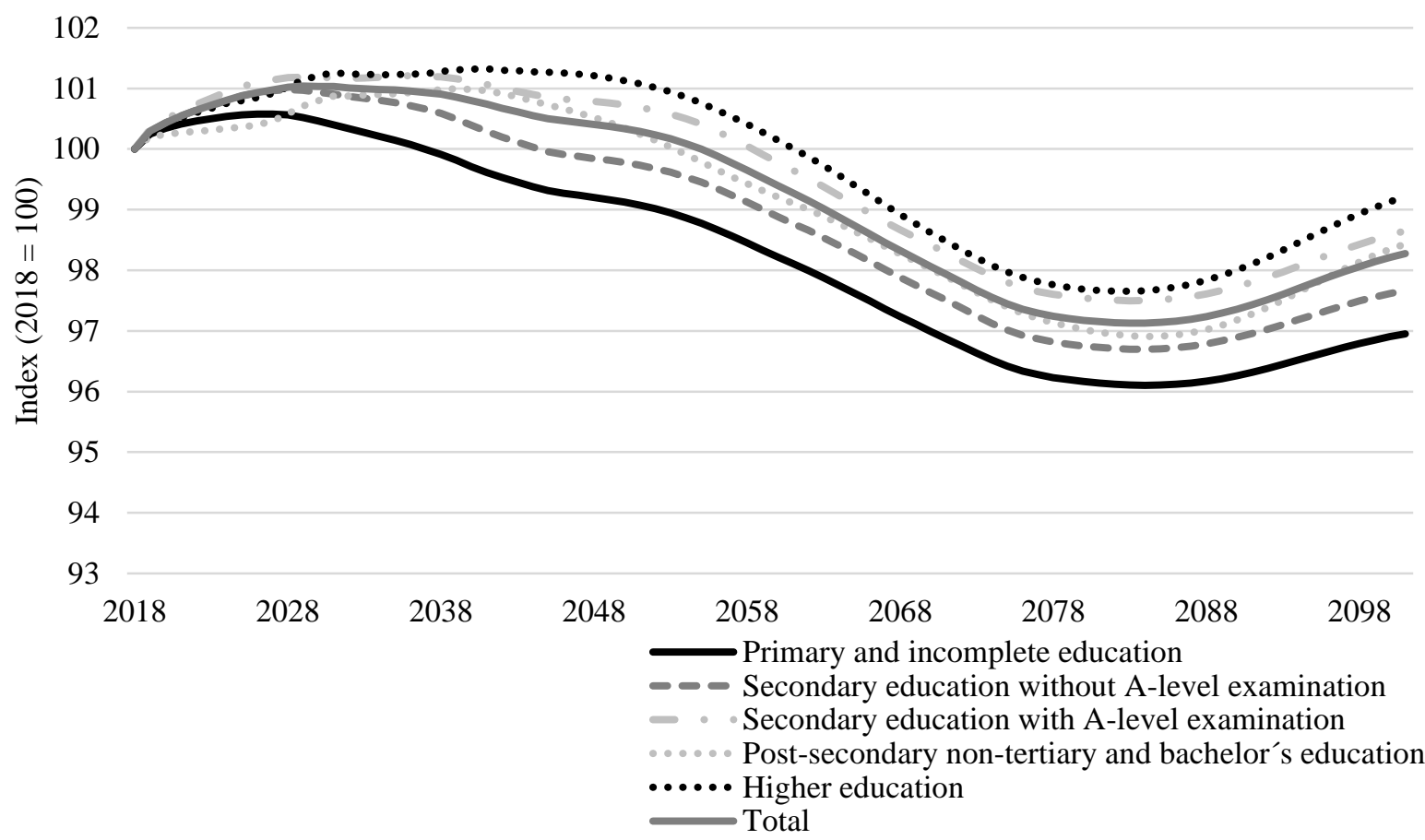

Source: the authors.

From the perspective of the international comparison, we used data estimated by the IMF, see following Figure 6. The loss estimated by the IMF for the Czech Republic is significant, about 0.5 percentage points from the total factor productivity. It was one of the most important decrease. Similar situation stands for Latvia, Lithuania or Hungary.

Figure 6: Demographic Impact on Annual TFP growth over 1984 - 2007 (in \%)

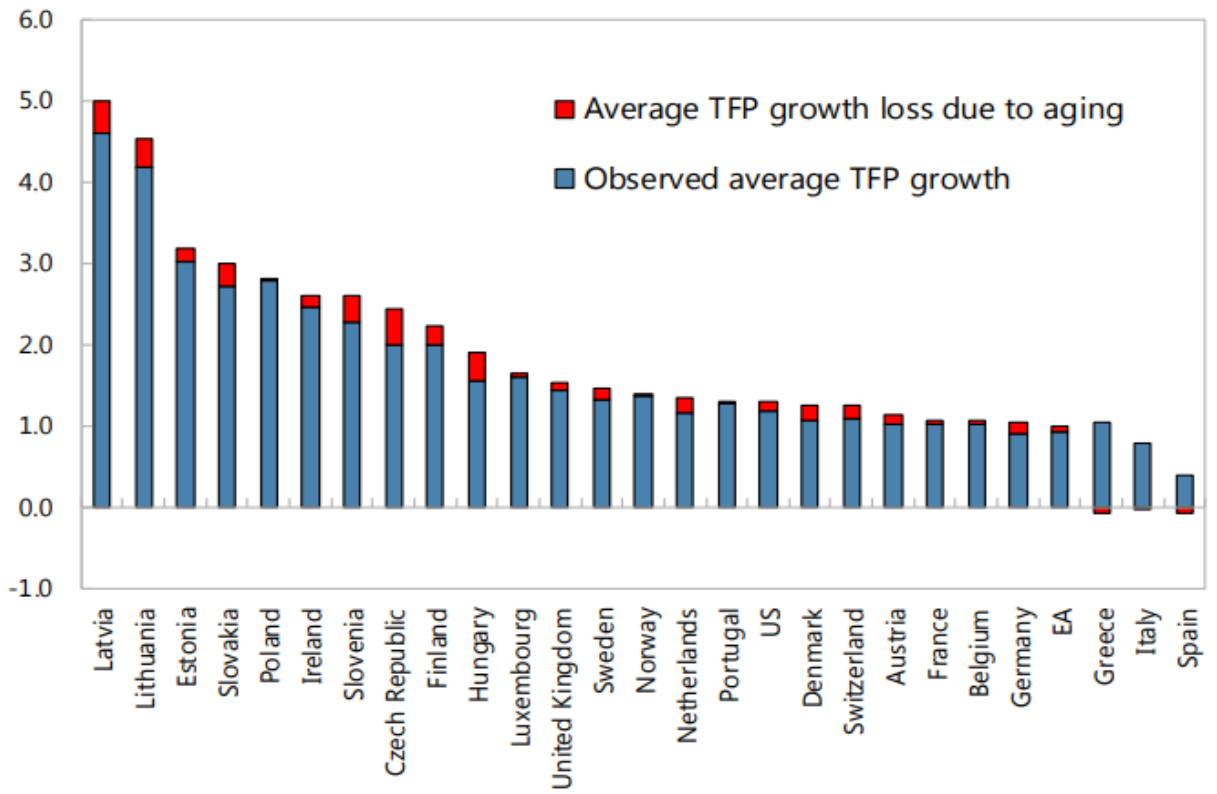

Source: European Commission and IMF staff calculations. 


\section{Conclusion}

The problem of labour productivity and population ageing is not new. In western countries this issue has been discussed for long time. The fundamental question is how the society will absorb the changes in the structure of labour and how the potential loss of capacities will be compensated. In many countries where ageing presents it is a combination of migration and technological progress. In some areas such as education, health and social care the substitution of human work by robots is less probable.

The research aimed at industries and attained education level is very important since we cannot expect that ageing effects will proportionally affects all areas of the economy. We focused on the labour productivity and wages as proxy measure for the productivity. In this sense, we constructed relative productivity measures and we combined them with official demographic projection. The most important outcome of our paper lies in the estimate of demographic contribution to labour productivity index, ceteris paribus. The labour productivity index is a broader category that needs further detailed elaboration, mainly from the perspective of economic consequences such as estimated economic activity and estimated demand for the products of the industries. Our approach is relatively new and exceptional in the Czech Republic. On the contrary, this issue has been discussed in western countries for several years. We think that similar studies should be comprised in the country's ageing preparation strategies.

The problem described within the paper tackled just one economic aspect of population ageing. The productivity model described above will be further studied and estimated labour productivity index will be used as parameter for CGE model within our future research.

\section{Acknowledgements}

The paper was institutionally supported by the long-term research scheme of the Faculty of Informatics and Statistics at the University of Economics in Prague and by the grant scheme GAČR No. 19-03984S “Economy of successful ageing”.

\section{References}

[1] Aiyar, S., Ebeke, C., Shao X. 2016. The impact of workforce aging on European productivity. IMF Working Paper No. 6. Washington, D.C. : International Monetary Fund, 2016.

[2] Aubert, P., Crépon, B. 2003. La productivité des salaries âgés: Une tentative d'estimation. In Economie et Statistique, 2003, iss. 363, pp. 95-119.

[3] Grönqvist, C. 2009. The effect of labour force ageing on productivity in Finland. In Bof online, 2009, vol. 2019, iss. 7.

[4] Junka, T. 2003. Maailman kilpailukykyisin maa? Tuottavuus ja investoinnit Suomessa 1975 - 2000. VATT Research Report No. 95. Helsinki : Government Institute for Economic Research, 2003.

[5] Lassila, J., Valkonen, T. 2008. Population ageing and fiscal sustainability of Finland: A stochastic analysis. Bank of Finland Research Discussion Papers No. 28/2008. Bank of Finland : Helsinki, 2008.

[6] Mahlberg, B., Freund, I., Prskawetz, A. 2013a. Ageing, productivity and wages in Austria: Sector level evidence. In Empirica, 2013, vol. 40, pp. 561-584.

[7] Mahlberg, B. et al. 2013b. Ageing, productivity and wages in Austria. In Labour Economics, 2013, vol. 22, pp. 5-15.

[8] Miskolczi, M., Langhamrová, J., Fiala, T. 2011. Unemployment and GDP. In 5th International Days of Statistics and Economics 2011. Prague : University of Economics in Prague, 2011. ISBN 978-80-86175-77-5. 
[9] Newburger, E. C. 2001. Home computers and internet use in the United States. Current population report, Series P-23, No. 207. Washington, D.C. : U.S. Department of Commerce, U.S. Census Bureau, 2001.

[10] Oster, S. M., Hamermesh, D. S. 1998. Aging and productivity among economists. In The Review of Economics and Statistics, 1998, vol. 80, iss. 1, pp. 154-156.

[11] Prskawetz, A. et al. 2005. Decomposing the change in labour force indicators over time. In Demographic Research, 2005, vol. 13, iss. 7, pp. 163-188.

[12] Prskawetz, A. et al. 2007. The relationship between demographic change and economic growth in the EU. Research Report No. 32. Vienna : Vienna Institute for Demography, Austrian Academy of Science, 2007.

[13] Skirbekk, V. 2008. Age and productivity potential: a new approach based on ability levels and industry wide task demand. In Prskawetz, A., Bloom, D. E., Lutz, W. (eds.) Population ageing, human capital accumulation, and productivity growth. In Population and Development Review, 2008, vol. 34, pp. 191-220.

[14] Stam, C. 2009. Knowledge and the ageing employee: A research agenda. In European Conference on Intellectual Capital. Haarlem : Holland University of Applied Sciences, 2008.

[15] Tang, J., MacLeod, C. 2006. Labour force ageing and productivity performance in Canada. In The Canadian Journal of Economics, 2006, vol. 39, iss. 2, pp. 582-603.

\section{Appendix}

Classification of Economic Activities (CZ-NACE)

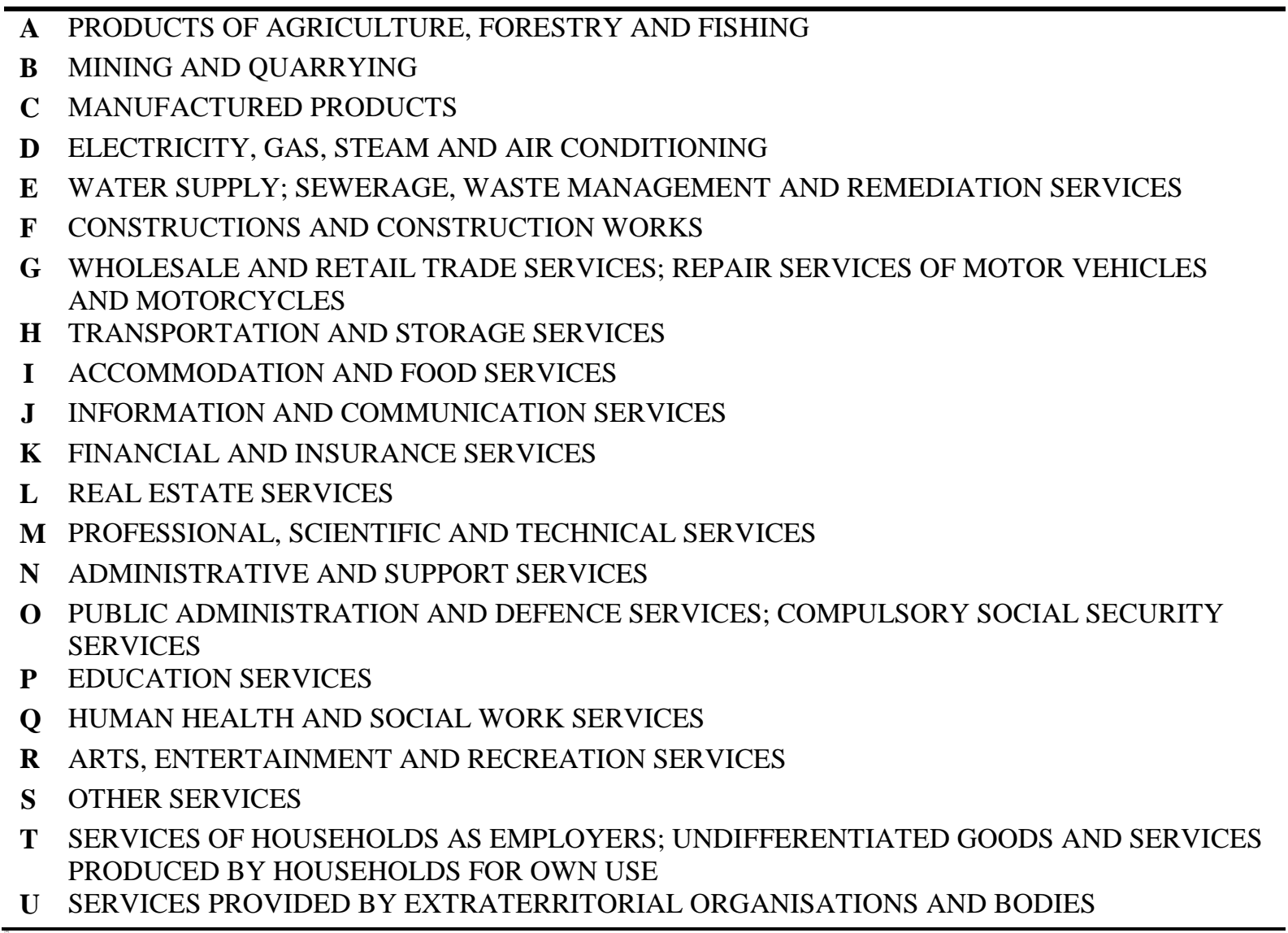

